\title{
How to Teach about the Holocaust? Psychological Obstacles in Historical Education in Poland and Germany
}

\section{Michal Bilewicz, Marta Witkowska, Silviana Stubig, Marta Beneda and Roland Imboff}

In 2000, a group of high-ranking political, religious and civil society leaders, educators, historians and survivors assembled in Stockholm and drafted the Stockholm Declaration about Holocaust education and remembrance (Assmann 2010). The declaration, signed by the representatives of 46 governments, included a pledge to "promote education, remembrance and research about the Holocaust, both in those of our countries that have already done much and those that choose to join this effort", as well as commitment to "promote education about the Holocaust in our schools and universities, in our communities and encourage it in other institutions" (Allwork 2015, p. 6). The most recent analysis of historical education in 135 nation states (Carrier et al. 2015) showed that in approximately half of

M. Bilewicz $(\bowtie) \cdot$ M. Witkowska $\cdot$ M. Beneda

University of Warsaw, Warsaw, Poland

e-mail: michalbilewicz@gmail.com

S. Stubig

University of Cologne, Cologne, Germany

R. Imhoff

Johannes Gutenberg University, Mainz, Germany

(C) The Author(s) 2017

C. Psaltis et al. (eds.), History Education and Conflict Transformation, DOI 10.1007/978-3-319-54681-0_7 
these countries, Holocaust is part of teaching curricula-most frequently covered within history curricula, but also in human rights education, ethics, philosophy and general social studies. In Europe, knowledge about a Holocaust is directly taught in almost all national education systems (except of Moldova, Ukraine, Norway and Slovenia, where it is referred to only indirectly, and Iceland where the Holocaust is not part of the historical education).

Apart from committing themselves to encourage and spread education about the Holocaust, the signatories of the Stockholm Declaration about Holocaust education mentioned also current problems, such as racism, xenophobia, discrimination and antisemitism that could be eradicated by successful Holocaust education. Therefore, the aim of educating about the Holocaust is not only to provide knowledge about this prototypical genocide (Mazur and Vollhardt 2015), but also to change attitudes of young people in order to prevent antisemitism, to raise awareness about intergroup violence and to better understand consequences of prejudice, discrimination and processes of conflict transformation. This is why it is of crucial importance to evaluate how well these tasks are met by schools.

This chapter presents results of different empirical studies on the effects of Holocaust education in Germany and Poland. ${ }^{3}$ Based on this research, we will outline the main obstacles in Holocaust education. Most of these obstacles are directly caused by interpreting the Holocaust on the grounds of students' national identities and ethnic membership, therefore potentially posing a national identity threat, leading to competitiveness in victimhood and negation of the newly acquired knowledge. Based on that criticism, we will also propose several ways of overcoming these problems. Based on relevant social psychological research, we would like to propose three different approaches towards Holocaust education: an approach based on empathy and regret (Imhoff et al. 2012), moral-exemplars approach (Bilewicz and Jaworska 2013; ČehajićClancy and Bilewicz 2016) and an approach based on local identities (Stefaniak and Bilewicz 2016; Wójcik et al. 2010). Combination of these strategies could form an alternative to the dominant Holocaust education approach that is based on national identities and ethnic membership salience. 


\section{Failures of Holocaust Education: The German Case}

Currently, the Holocaust seems to be an omnipresent topic in German public discourse, which may be supported by the fact that on every single day there is an average of almost two prime-time television broadcasts on the topic of National Socialism and the Holocaust (Schmidt-Denter and Stubig 2011). At the same time, communication on National Socialism and the Holocaust within the family-as far as still available and not concealed-seems to follow homogenous patterns, characterized by stories of resistance, personal victimization and war suffering (Brockhaus 2008). These communication patterns and the continuous fading away of eyewitnesses reduce the relevance of family as an important source of knowledge for learning about National Socialism and the Holocaust. As research shows, German youth do not regard biographical points of reference in their families as important (Ahlheim and Heger 2002; Welzer 2004).

This makes formal school education the primary source of learning about National Socialism and the Holocaust. Indeed, in the study by Stubig (2015), 234 pupils from North Rhine-Westphalian high schools (9th to 12th grade) were asked about sources of their knowledge about National Socialism and the Holocaust. The majority of the pupils $(63 \%)$ listed their school as the main source of knowledge on this topic, underlining especially the importance of history lessons. Among other relevant sources were television (10\%) and family (10\%). When the teenagers were asked about the trustworthiness of these different sources of knowledge, they pointed to history classes as to the most reliable source, whereas family and television were described as markedly less trustworthy (Stubig 2015). These findings show that pupils perceive their history lessons and school education as an important source of information about National Socialism and the Holocaust. By the same token, this suggests a remarkable responsibility put on the teachers designing classes on this topic.

It should be noted that teaching guidelines for history education in Germany are relatively vague in their recommendations for devising history lessons. This gives educators a lot of freedom in choosing their methods of teaching and designing classes. Although the topic is recommended to be introduced in history lessons in nineth grade (Ministerium für Schule und Weiterbildung des Landes NordrheinWestfalen 2007), German students are confronted with the topic of 
the Holocaust and National Socialism much earlier as it is also a central topic in literature, religion, politics, fine arts, social science, music and pedagogy classes (Stubig 2015). Another important aspect of education on National Socialism and the Holocaust that should be mentioned is the amount of time that teachers devote to this topic. In general, there seems to be a striking difference between the amount of time spent on teaching about National Socialism and the Holocaust and that devoted to other historical topics. Not only in North Rhine-Westphalia, but also in other German regions, twice as much time is dedicated to the topic of National Socialism and the Holocaust in comparison with remaining historical problems (Schmidt-Denter and Stubig 2011), adding to a period of intensive learning lasting at least two and up to six months (Stubig 2015). Yet, although the majority of teachers tend to devote a great amount of time to the issue of National Socialism and the Holocaust, there seems to be a considerable variance in the ways of teaching about this topic.

In the view of history teachers, the ultimate aim of history lessons about National Socialism and the Holocaust is to generate strong emotional reactions in youth (Henke-Bockschatz 2004; Brockhaus 2008; Keupp 2008; Kühner and Langer 2008). This claim rests on the assumption that intensive affective reactions (and even shock) increase empathy and social awareness, as well as the likelihood of accepting one's group moral responsibility, which then leads to a decrease in radical attitudes. All of this serves the ultimate goal of preventing a second Holocaust (Abram and Heyl 1996; Keupp 2008; Kühner and Langer 2008). This approach is present in a variety of didactic methods that, again, seem to differ from those applied to other historical topics (Schwendemann and Marks 2002). These methods focus especially on affective processes in contrast to the more traditional cognitive approaches (Brockhaus 2008; Schwendemann and Marks 2002) and may consist of textbook analyses, students' presentations, using video documentations and movies, visiting exhibitions and memorials or interviewing eyewitnesses (Brendler 1994; Heyl 1996). In particular, the latter methods seem to be especially effective in promoting emotional access to the topic of the Holocaust in an especially intense manner and are thus widely prevalent. Across a number of studies, German high school students report high levels of emotionality in reaction to teaching units on the topic (Brusten and Winkelmann 1992, 1994; Brendler 1997a, b; Cisneros 2008; Meier 1997; Schwendemann and Marks 2002). 
Nevertheless, enthusiasm about this is not ubiquitous. Teachers repeatedly report problems during their lessons due to pupils' reactions to the topic, ranging from disinterest to defensiveness. Students' little knowledge about National Socialism and the Holocaust together with such negative reactions tends to cause feelings of frustration in teachers (Brockhaus 2008; Schwendemann and Marks 2002). Frequently, teachers try to overcome this situation by employing more emotionally shocking sources of information and may end up exaggerating, in terms of both quantity and quality (Brockhaus 2008; Heyl 1996; Schneider 2004).

The way in which pupils tend to be affected by Holocaust education may be described as a remarkable conundrum. Although the Holocaust is frequently found to be a historical episode that evokes the highest levels of interest and curiosity (Cisneros 2008; Stubig 2015) and receives much attention in terms of time and teaching intensity, students' level of knowledge on this topic seems to be surprisingly low (Brendler 1994; Schwendemann and Marks 2002; Zülsdorf-Kersting 2007). Pupils report strong feelings of shame and guilt when being confronted with this chapter of German past (Brockhaus 2008; Rommelspacher 1995), at the same time experiencing other affective states, such as feelings of being left alone accompanied by unresolved emotions of disgust, shock or anxiety (Brendler 1994; Glück and Wagensommer 2004; Rommelspacher 1995; Schwendemann 2004). This may be one of the possible solutions for the conundrum described. If pupils are indeed emotionally overburdened, a process of knowledge acquisition and information processing is likely to be inhibited by such strong emotions and high levels of arousal (Anderson 2007; Easterbrook 1959). Alternatively, it might lead to historical defensiveness that blocks any empathic response to the victims (Bilewicz 2016).

Apart from these emotional processes that may result in poor knowledge acquisition, Holocaust education may also have an impact on social identity development. Since the topic of National Socialism and the Holocaust is introduced in nineth grade, so in the early years of adolescence, pupils exposed to it tend to be in the most critical moment of their identity construction and therefore may experience an increased interest also in their national group's history. In a recent study (Stubig 2015), five classes of nineth-grade high school pupils in North RhineWestphalia were surveyed twice: before and after their teaching unit on the Holocaust. The survey examined their attitudes towards Europe, 
national attachment and pride, tolerance towards others, their opinion about national feelings, antisemitism, xenophobia and xenophilia. In the second survey, the pupils were also asked to evaluate the lessons they had attended-their aim and the methods used-as share the reactions these lessons evoked.

For most variables measured in the study, there was no significant difference between the survey administered before and after the lessons on National Socialism and the Holocaust. In stark contrast to the explicated aim of such an education, there were no observed improvements in attitudes towards Europe, increased tolerance, or decreases in neither xenophobia nor antisemitism. The teaching unit only had an effect on measures of national identification, as students declared less national pride and had less positive attitudes towards national feelings after Holocaust education programmes than before (Stubig 2015). While this might be seen as an intended effect, two details are remarkable here. First, these reductions in national pride were not accompanied by synchronous reductions in prejudice and outgroup negativity. Second, of all items that tapped into pride for different aspects of being German, the effect was mostly driven by aspects of national identity that could be construed as democratic, post-Nazism identity. As an illustration, after the lesson students were less proud with regard to "current democracy and the democratic constitution" or "the fall of the wall and the peaceful transition." In contrast, arguably more problematic sentiments such as "pride for German history", "pride for German soldiers' bravery in the world wars", "pride for Germany's standing in the world" and "pride for typically German virtues like diligence, discipline, and reliability" were not significantly reduced at single item level. It is well established that-compared to other nations-German adolescents show relatively low levels of national attachment and pride (Bar-On et al. 1997; Schmidt-Denter 2011; Smith and Jarkko 1998; Smith and Seokho 2006; Westle 1999), and the reported results (Stubig 2015) suggest that this may - at least partially — be a direct effect of Holocaust teaching. In the light of the many detrimental effects on nationalist pride throughout the literature (e.g. Golec de Zavala et al. 2013; Mummendey et al. 2001), this may serve as an indicator of educational success. At the same time, many developmental scholars argue that such national identification is an important part of a normal identity development. By asking "who am I" and defining self by one's affiliation to groups, young people construe their self-image which is experienced as a consistent self 
over past and future times (Fend 1991; Mayer et al. 2006). Constructing identity is the ability to reflect and problematize even negative aspects of self-image, which leads to a balanced identity achievement (Krejci 1995), whereas the elimination of identity aspects, like skipping national and historical acquisitions of self, might lead to difficulties in identity construction (Rommelspacher 1995). It is certainly open to debate whether adolescents as future citizens really need to form strong ties to their nation and thus establish a strong national identity. Independent of the outcome of this dispute, however, it seems remarkable that in the present context, the identification with democratic, post-fascist aspects of the national identity decreased over the course of Holocaust education, whereas identification with more problematic aspects like dominance and bravery did not.

Being asked about their experience of learning about National Socialism and the Holocaust in history lessons, pupils revealed their conviction about what they should have learned in this unit: next to acquisition of declarative knowledge which scored on first place, students secondly agreed in the idea that the aim of the unit on National Socialism and the Holocaust was to teach them how to think and talk about this topic in a socially desired manner (Stubig 2015). These results confirm statements of university students and pupils which attest appeals of consternation to their history lessons (Stubig 2015) and even expressed feelings of being indoctrinated (Brockhaus 2008). This result reveals a paradox in education on National Socialism and the Holocaust. While this topic is - according to the curriculum-meant to foster maturity and responsibility in social and political aspects of democratic life, factually it seems to leave students with the impression that the goal of history lessons is to teach or suggest pre-assembled communication patterns. Further research is required to verify the occurrence of such lesson outcomes.

\section{Failures of Holocaust Education: The Polish Case}

Following the Declaration of Stockholm International Forum on the Holocaust signed by the President of Poland in 2000, education about the Holocaust has been an important element of Polish education system. Since 2005, the Holocaust Memorial Day (April 19) is officially observed in Polish school system. Holocaust education in the current educational programme is introduced at several stages as part of the 
core curriculum: in primary schools (Polish language; History and civics classes), lower-secondary school (Polish language; Civics) and uppersecondary school (History; Polish language; Civics). Many schools visit the death camps and other Holocaust memorial sites (e.g. Majdanek, Auschwitz, Polin Museum of the History of Polish Jews). This structure, together with existing textbooks and teaching curricula, provides bases for extensive coverage of Holocaust-related topics in the course of education (Szuchta and Trojański 2012). It is also mirrored in students' perception of school education as one of the most important sources of knowledge about the Holocaust and Jewish history (Bilewicz and Wójcik 2009). More than three-quarters of students from small towns in Poland declared that they learned about these topics in their schools. Family stories, tours or newspapers and books were indicated less often as sources of knowledge about Jewish history and the Holocaust. At the same time, teachers often do not know the international recommendations for teaching about the Holocaust and possible programmes and curricula (Węgrzynek 2006; Szuchta 2006). They also devote significantly less time to the topic of Holocaust than recommended (Szuchta 2013).

The last decades brought some positive developments in regard to the content of school lessons about the Holocaust. While under Communist rule students were taught about the Jewish tragedy as a facet of the Polish martyrdom, modern textbooks acknowledge the pan-European extent of the crime and its ethnic nature (see Ambrosewicz-Jacobs and Szuchta 2014). However, despite the progress in reducing the existing gap between historiography and education, great parts of the Holocaust history depictions remain unchanged even in the most modern Polish textbooks (Gross 2010). This particularly applies to historical discoveries about the Polish involvement in crimes against Jews that manifestly contravenes the collective memory framework of Poles as victims (but not perpetrators) of the WWII (Gross 2014). The very emotional public debate after the publication of the Jan Thomas Gross' book about the crime on the Jewish population of Jedwabne (Gross 2001) is a clear instance of difficulties in accepting unfavourable historical facts (Ambrosewicz-Jacobs and Szuchta 2014). These difficulties are obviously mirrored in the school education about the crime. The very rare attempts to evaluate the effectiveness of Polish teaching about Holocaust show its mediocre results in reducing ethnocentrism and antisemitism (Ambrosewicz-Jacobs and Szuchta 2014). 
In order to test the effects of current Holocaust education in Poland, the Center for Research on Prejudice at the University of Warsaw conducted a survey that assessed three key outcomes of such education: factual knowledge about the Holocaust, understanding of historical relations between Poles and Jews and attitudes towards Jews. Above one thousand students from 20 high schools in the capital city of Poland participated in the study during their normal school activities (Witkowska et al. 2015).

The factual knowledge about the Holocaust was assessed with three questions concerning the Warsaw Ghetto Uprising, a revolt that took place in Nazi-occupied Warsaw as a form of resistance to the liquidation of the Jewish ghetto (by deporting last remaining Jews to Treblinka death camp by the German occupants). Participants were asked to indicate the exact year in which the uprising took place, the name of the main commander and whether the uprising was a military success. In order to check whether the level of students' knowledge about the history of Polish Jews diverges from the level of their general historical knowledge, the participants were also asked about the outcomes of other four Polish national uprisings. In order to assess students' understanding of the historical relations between Poles and Jews, we asked them to evaluate the amount of help offered by Poles to those Jews who were fighting in the Warsaw Ghetto or hiding on the "Aryan side" of the Polish capital. The answers were given on a five-point scale, from "The amount of help was definitely insufficient" to "The amount of help was definitely too extensive" with a midpoint statement- "The amount of help was just sufficient."

The attitudes towards Jews were tested with three different measures. A "feeling thermometer" captured the "temperature" of feelings towards Jews on a scale ranging from very cold, negative feelings to very positive, warm feelings. A scale of contact intentions assessed readiness to engage in contact with Jewish peers and to learn about Jewish culture. Finally, a social distance scale measured the acceptance of Jews in one's social environment-family, school and neighbourhood.

In order to test the effectiveness of Holocaust education, we asked students to provide information about their final grades in history and about the number of hours that have been devoted in their schools to the topic of the Warsaw Ghetto Uprising. Based on this information, we created two indicators measuring the impact of school education: accomplishment (grades) and extensiveness of the course (number of hours). 
The data from the survey showed that one in four high school students did not know the most basic facts about the Warsaw Ghetto Uprising-26\% of the participants did not know the exact year of its outbreak, 23\% thought that the uprising was a military success and $44 \%$ were not able to select its commander's name from the list. However, the wrong answers to the questions concerning the history of Polish Jews did not stand out from the answers assessing the level of general historical knowledge, as $31 \%$ of the participants gave wrong answers to other questions about historical facts unrelated to the history of the Holocaust. When asked about the amount of Polish help offered to Jews, participants most often chose the answer "sufficient" (39\%), whereas $22 \%$ considered the amount of Polish help as "slightly too extensive" or "definitely too extensive."

Within the section measuring attitudes, the students demonstrated considerable prejudice towards Jews-more than half of the participants (54\%) declared cold, negative feelings. A similar pattern was obtained for the measure of contact willingness - the majority of the young Poles indicated that they would prefer not to have contact with people of Jewish origin. Almost half of the students said that they would react negatively to Jewish classmates (40\%) or to Jewish neighbours (44\%).

In order to determine how school education is related to knowledge and attitudes of students, we conducted a series of correlation analyses (see Table 1). The results showed that factual knowledge is practically unrelated to history school education; hence, those students who knew the correct answers are likely to have acquired their knowledge outside

Table 1 Correlation between knowledge, understanding of history, attitudes and school education among Warsaw students. Pearson correlation coefficients $(r)$

\begin{tabular}{lll}
\hline & Grade in history & Course extensiveness \\
\hline Correct date of Warsaw Ghetto Uprising & 0.03 & -0.03 \\
Correct name of Uprising ghetto commander & $0.09^{* *}$ & -0.03 \\
Knowledge about the outcomes of the Uprising & 0.02 & -0.02 \\
Biased assessment of Polish role in the Uprising & $0.08^{*}$ & $0.14^{* *}$ \\
Positivity of feelings towards Jews & $0.09^{* *}$ & -0.07 \\
Willingness to contact Jews & 0.05 & $-0.07^{*}$ \\
Acceptance of Jews in close environment & 0.04 & -0.02 \\
\hline
\end{tabular}

${ }^{*} p<0.05,{ }^{* *} p<0.01$ 
the school environment. We observed only a weak correlation between the correct answers to the questions on factual knowledge and the participants' grades in history, and no relationship with extensiveness of teaching. Therefore, school's effectiveness in conveying knowledge about the Holocaust proved to be very low.

Interestingly, both extensiveness of school Holocaust education and students' grades seem to be significantly related to their idealized views of their national history. The more extensive the school teaching on the Holocaust was, the more likely the students were to perceive the amount of help offered by Poles to Jews as too big. A relatively weak relation was observed also in case of history grades: the students with good grades were more likely to perceive the amount of Polish help offered to Jews as too extensive, comparing to their peers with lower grades. Among the students with best grades, $26 \%$ believed that the amount of Polish help offered to Jews was more than sufficient, whereas among the students with worst grades this belief was shared by $20 \%$.

The direct relationship between school education and attitudes towards Jews seems to be unclear and inconsistent (see Table 1). We observed no relation between the amount of Holocaust education and acceptance of Jews in the close social environment. School accomplishments were weakly related to attitudes towards Jews-the better grades the students achieved in history, the warmer feelings they declared towards Jews. The extensiveness of the teaching, in turn, was negatively related to willingness to have a contact with Jews; i.e., willingness was lower among students who had more classes devoted to the topic of the Holocaust. At the same time, we found that this negative effect of school teaching was rooted in the biased and idealized perception of PolishJewish wartime relations, i.e. the overestimation of Polish help offered to Jews. Students who had extensive course on the history of the Holocaust acquired convictions that their ancestors offered extensive help to Jews and this, in turn, deteriorated their attitudes towards Jews. Therefore, efforts made by schools to fight prejudice seem to be not only insufficient and inconsistent but even counterproductive: a biased school education about the Holocaust might increase negative attitudes towards Jews. 


\section{Psychological Obstacles: Historical Defensiveness And Aversive Emotions}

The German and Polish examples presented above suggest that current forms of Holocaust education in Polish and German school programmes are, in fact, not effective in eradicating antisemitism and making students more tolerant. The only meaningful change is observed in loosening their identification and pride of national group membership. Apart from inappropriate school education and defensive approaches of governments, the failures of Holocaust education could be affected also by psychological processes involved in learning about negative history of one's national group.

Information about the perpetratorship (in case of Germans) or bystandership (in case of Poles) of fellow ingroup members during the Holocaust can severely threaten students' social identities. Among strongly identifying individuals, there is a pronounced desire to view their own nation in a positive manner (Tajfel and Turner 1979). In fact, explanations of the Holocaust history depend on the strength of students' national identification (Bilewicz et al. 2016), and they affect students' contemporary intergroup attitudes (Imhoff et al., in press). The review of studies performed in several national contexts showed that when people are confronted with a historical narrative about the crimes committed by their nation, they most commonly deny the facts and do not feel responsible, guilty or ashamed (Leach et al. 2013). People can use the whole system of emotion regulation in order to downregulate negative emotions resulting from such confrontations with history (Bilewicz 2016). For instance, after learning about ingroup members' misbehaviour during the Holocaust, one can avoid contact with Jews (as they become reminders of such negative past), detach from national history, question and criticize the source of information (e.g. teacher, textbook or historian) and engage in victimhood competition with Jews (e.g. by pronouncing German losses, such as Dresden bombings, or Polish victimhood during Warsaw Uprising or Katyn massacre). Finally, one can employ a biased structure of explanation or engage in conspiracy theorizing (e.g. different forms of Holocaust revisionism and denial). Such reactions are relatively common when people are faced with information about ingroup members' involvement in a genocide-either as perpetrators or as passive bystanders.

Another important question is as follows: What kind of emotions should be elicited by Holocaust education in countries characterized by 
the dominant collective memory of being a nation of perpetrators (e.g. Germany and Austria), collaborators (e.g. Ukraine, Latvia, Lithuania and Hungary) or passive bystanders (e.g. Poland) of the Holocaust ${ }^{1}$ ? Should teachers try to evoke highly aversive feelings of (group-based) guilt and shame as these are frequently believed to be antecedent of reparative tendencies? Or does such a strategy overburden students emotionally and therefore does not meet its goal of ultimately improving intergroup relations?

A plethora of research points to the allegedly positive outcomes of group-based guilt (Ferguson and Branscombe 2014). Guilt signals that an intergroup relationship is damaged and needs to be repaired (Branscombe et al. 2002), and is often connected to prosocial consequences such as reduced racism (Branscombe et al. 2007) and increased forgiveness (Hewstone et al. 2004). More specifically, guilt increases the motivation to make amends or to apologize (Brown et al. 2008; Imhoff et al. 2013; Tangney 1995). This has led several researchers to characterize guilt as a relationship-enhancing emotion that strengthens social bonds and attachment (Baumeister et al. 1995), thus playing a "pivotal role in alleviating group conflict" (Maitner et al. 2007, p. 224). Therefore, there are good reasons to indeed evoke negative emotions or even vicarious bad conscience for the deeds committed by Nazi Germans and their collaborators.

Although these examples seem to allow the straightforward conclusion that teaching strategies incorporating shaming or guilt induction are (even if ethically, psychologically and educationally questionable) indeed effective in promoting positive intergroup attitudes, the reality is more complex. In fact, it is conceivable that recipients merely learn (about) teachers' expectations and comply with their norms rather than internalizing this position. Moreover, they may even reject this message and demonstrate reactance to this perceived pressure to adopt a politically correct opinion. As has been argued for decades in the context of secondary antisemitism (Imhoff and Banse 2009), such teaching strategies might even backfire as the Jewish victims are likely to become potentially blamed for these aversive feelings of guilt and shame. Even though the original source of them was the teacher, students might easily start perceiving Jews as a lobby group standing behind such forms of education or might associate Jews with the negative classroom experience by which "every living and surviving Jew becomes the witness and the accused at the same time" (Broder 1986; p. 38, original in German, translation by 
authors). So, is it indeed true that certain confrontational ways of dealing with the Nazi past evoke guilt and reparation intentions at the explicit verbal level but create resentment at the implicit level?

Very much in line with such a proposition, reminding young German students of ongoing suffering of Jewish Holocaust victims led to higher self-reports of feelings of group-based guilt and greater claims of reparation intentions (Imhoff et al. 2013). The very same manipulation also led to a decrease in antisemitism compared to a baseline measurement three months earlier (Imhoff and Banse 2009). Taking the differentiation between public conformity and private acceptance vs. resentment seriously, however, led researchers in the same study to implement another manipulation: wiring up participants with the information that this will help the experimenter to detect untruthful responses (bogus pipeline). Very much in contrast to the group without a bogus pipeline, it did not decrease but increase antisemitic responding, making participants express more prejudices against Jews. This finding strongly suggests that some forms of confrontation will lead to conformity with whatever is perceived as desired but create reactance and prejudice increase on the implicit level.

Some studies suggest that precisely because guilt is such an aversive experience, it is associated with not only greater reparation intentions but also feelings of discomfort in face of victims or their descendants which suppresses the willingness to engage in interpersonal contact with them (Imhoff et al. 2012). This is why any guilt-inducing Holocaust education might not address its aims in improving current intergroup relations of Poles, Germans or Hungarians with Jews. It might in fact increase antisemitic responses among young people instead of constraining them. In order to overcome the aversive emotional guilt-driven reactions, as well as the historical defensiveness derived from national identities that are salient in traditional forms of Holocaust education, we would like to propose three alternative educational strategies based on recent social psychological research on post-genocide reconciliation. These three approaches are aimed at overcoming the defensiveness and emotional regulation stemming from strong national identities. In order to achieve such goal in Holocaust education, one should focus teaching on individual and local narratives instead of national-level ones. 


\section{Proposal 1. Regret Instead of Guilt. Empathic EDUCATION}

Due to the aversive character of guilt (Imhoff et al. 2012), one could doubt about the use of this emotion in Holocaust education. Social psychological research shows however that milder forms of negative emotions, such as feelings of regret, could be associated not only with the self-reported intentions to engage in intergroup contact but also with money allegedly donated in one's name to the cause of promoting intergroup contact. Studies of collective regret (Imhoff et al. 2012) found that raising this emotion can increase contact-promoting actions among descendants of the perpetrator group (i.e. German high school students) as well as descendants of the bystander group (i.e. inhabitants of the Polish town Oświęcim, location of the Nazi death camp Auschwitz). Regret, as the same studies suggest, can be conceptualized as an empathic emotion that arises from a focus on the plight of the victims (e.g. "Jews were killed") rather than a focus on the cruelties of the perpetrators (e.g. "Germans killed Jews").

On a relatively abstract level, these findings therefore resonate with the effects ascribed to the American TV show "Holocaust" aired in German television in 1978. Attacked by many as a trivialization of history and applauded by many for not expressing an accusation of collective guilt against all Germans (Reichel 2004), many commentators agree that this personalized TV drama constituted a turning point in public German discourse about the Holocaust. Through identification with the portrayed Jewish family Weiss, many Germans, for the very first time, empathized with the Jews (Brandt 2003), and this slowly initiated an increasing awareness and a greater willingness to deal with the topic at all. Therefore, psychological studies and case studies of media effects seem to converge in their suggestion that creating chances to empathize with humanized victims might be less aversive and potentially more effective than creating a sense of vicarious guilt around the Holocaust.

Empathy-based Holocaust education has been proposed by both theorists (Riley 1998) and practitioners of Holocaust education (Facing History and Ourselves project; Schultz et al. 2001). For this purpose, a great educational resource for potential use could be wartime diaries (e.g. diaries of Anne Frank or Dawid Rubinowicz in case of primary school children or Calel Perechodnik's diaries in case of young adults) or testimonies (e.g. the Visual History Archive of the USC Shoah 
Foundation). Such forms of education can overcome the national-collectivistic approach represented in many existing textbooks and school curricula (presenting the "whole nations" as actors, focussing on national leaders and military history).

The only risk in empathy-based education could concern students' psychological reactions to extreme acts of suffering. A recent study performed on a group of 854 young visitors to Auschwitz-Birkenau State Museum found that approximately 13\% of them developed secondary post-traumatic stress disorder syndrome related to the visit in $\mathrm{KL}$ Auschwitz (Bilewicz and Wójcik 2016 ${ }^{2}$ ). At the same time, these visitors improved their overall attitudes towards Jews and Jewish victims of the Holocaust (Wójcik and Bilewicz 2012). This study found that PTSD syndrome was particularly visible among young people that reacted to KL Auschwitz visit in a highly empathetic way-by including the Jewish victims into their structure of self. These findings suggest that empathybased education in memorial sites, however effective in attitude change, has to be carefully prepared by the teacher or facilitator working with the students intensively prior to a visit in a memorial site.

\section{Proposal 2: Employing Moral Exemplars}

According to analyses of history textbooks used in Polish schools, the idea of Poles helping Jews during the Second World War is among the common ones conveyed in school teaching. At the same time, not enough attention has been devoted to avoid simplification and banalization of such heroic help, and to objectively present its instances, without omitting the broader context of Polish-Jewish relations which were complex and often violent (Ambrosewicz-Jacobs and Szuchta 2014; Szuchta 2013). That is why teaching about help offered to Jews happens to be misleading, which was demonstrated in the study of Polish high school students' historical knowledge presented in this chapter. Despite this failure in education, we believe that the more realistic and precise approach to wartime helping behaviour could provide an important opportunity for more meaningful Holocaust education.

The moral-exemplars model of reconciliation (Čehajić-Clancy and Bilewicz 2016) proposes that reliable depictions of heroic helpers can facilitate positive intergroup relations in post-conflict settings, among both victims and perpetrators, as well as bystanders. According to this model, heroic helpers stemming from the own national group or the 
adversaries in conflict could serve as moral exemplars, since they exhibited uniquely moral behaviour in comparison with their compatriots. In particular, the model suggests that presenting narratives about heroic helpers who decided to act morally and in opposition to the passive or active aggression of their group can restore impaired intergroup relations, by improving attitudes among descendants of historical perpetrators, victims and bystanders.

Research on Polish-Jewish youth encounter programme (Bilewicz 2007) showed that Holocaust-related topics present during such encounters suppressed positive effects of intergroup contact in improving mutual attitudes. However, narratives about moral exemplars proved to be effective in overcoming these obstacles. When the encounter was preceded by a meeting with a Polish heroic helper (i.e. a person awarded with the honorary title "Righteous among the Nations" for rescuing Jews), intergroup contact had a positive effect on young Poles' attitudes towards Israelis and Israelis' attitudes towards Poles. Documented stories of rescue (i.e. films, testimonies and photographs) catalysed also a positive effect of intergroup encounters between Bosniaks and Serbs in the context of the Bosnian War (Čehajić-Clancy and Bilewicz 2016). The exposure to such stories facilitated the positive effect of intergroup contact on beliefs in reconciliation and forgiveness.

Positive effects of moral-exemplars narratives were observed also outside of the intergroup contact setting. Interestingly, a study conducted in the context of the Armenian genocide demonstrated that an exposure to narratives about Turks who helped Armenians in 1915 increased Turks' willingness to engage in contact with Armenians and improved their attitudes towards them (Witkowska et al. 2016). Similar results were found in the context of the Second World War, where reminders of German heroic helpers, who rescued Jews during the Holocaust, proved to be effective in reducing the tendency of Germans to engage in temporal distancing from the Nazi past (Peetz et al. 2010).

Current empirical findings obtained in this area suggest that the use of heroic helpers' narratives-as long as it is free from simplifications and does not ignore the negative setting in which the heroic help took place (i.e. aggression or passivity of others) - may be an effective tool in reducing discomfort related to threatening past of one's group and may give a possibility of discussing difficult historical topics in the classroom. 


\section{Proposal 3: Working With Local Identities Instead of National Ones}

Most of the existing Holocaust education curricula use the national or ethnic groups as key agents in the historical narrative. It is known, however, that most defensive reactions to the history of the Holocaust stem from strong national identities (for a review, see Bilewicz 2016). Empathy-based approach and moral-exemplars-based approach suggest that student's attention can be redirected to individualized stories that allow to personalize education about the Holocaust. In a process of personalization, students' national identities become less salient which allows them to gain a new perspective and makes them more open to outgroup members and new narratives (Miller 2002). At the same time, personalized education can lead to subtyping: students can change their attitudes towards a given person (e.g. Anna Frank or Dawidek Rubinowicz), while at the same time remaining prejudiced and insensitive about other members of victimized nation (Brown et al. 1999). To overcome this problem, we suggest another approach, based on the local history education that incorporates psychological theories of common ingroup identity (Gaertner et al. 1993) and place attachment theory (Lewicka 2008).

Moreover, the local history approach suggests that it may be beneficial to expose students to the history of the Holocaust in their local environment and thereby include Jews into the common local identity (e.g. Varsovians, Berliners, Galicians). In most of the current Holocaust education programmes, the main focus is put on several key historical locations, such as Auschwitz and Treblinka death camps or the Warsaw Ghetto. Such an approach does not engage local identities and leads to the perception of the Holocaust as a geographically distant event, especially for those students who live in the places where numerous Jewish communities existed prior to WWII and their historical presence and destruction remains unacknowledged.

Recently, various educational institutions have attempted to overcome this problem by implementing local history approach using interventions such as presenting the local Holocaust narratives as a part of the history of Budapest (Zachor Foundation in Hungary), reminding Germans about their lost Jewish neighbours with memorial cobblestones in their hometowns (Stolperstein project by Gunter Demnig) or increasing interest in local Jewish heritage in small Polish towns (School of Dialogue 
programme by Forum for Dialogue Foundation). Such projects are in line with the findings of environmental psychology demonstrating that an increased interest in local history can improve intergroup relations by generating more inclusive social identities (Lewicka 2008, 2012).

In the in-depth study of one of these interventions (School of Dialogue programme), Stefaniak and Bilewicz (2016) assessed the specific mechanism responsible for the effectiveness of local history programmes. They found that such programmes increase student's interest in history and, at the same time, provide them with historical knowledge about the Jewish past. This, in turn, creates a situation in which students more readily include Jews into their collective identity (as historical fellow residents of the same space), which ultimately leads to the improvement of attitudes towards Jews, and even greater curiosity to learn Jewish history.

The local history approach can clearly facilitate successful Holocaust education. It brings the victims to the scope of students' understanding by decreasing the geographical-temporal gap between themselves and the Jewish victims of the Holocaust. The Holocaust may become personally significant to students only after they are able to properly understand the scale of the historical losses endured by their community, as well as by their local culture. Without that, there is a risk of distancing from the Holocaust and perceiving it as a typical "somebody-else's problem." In general, common ingroup identity approaches, when used in the context of Holocaust education, were found to increase one's sense of responsibility for the past and lead to intergroup reconciliation (Kofta and Slawuta 2013; Wohl and Branscombe 2005).

\section{SUMMARY}

German and Polish Holocaust education in its current form often does not fulfil its goals. A comparison of several nationwide surveys performed after 1989 showed a linear decrease of knowledge about the Holocaust in Polish population (Witkowska and Bilewicz 2014). This trend was observed in times when the country implemented Holocaust education in its curricula. Similarly, a survey performed 10 years after the massive public Holocaust education programme was implemented in Sweden found that more than $70 \%$ of Swedish teachers show vast ignorance about the Holocaust (Lange 2008). 
Apart from failures in providing knowledge, Holocaust education was also ineffective in changing attitudes. The results of studies from Poland and Germany presented in this chapter show that current Holocaust education fails to reduce antisemitism and promote tolerance among students. The only measurable effects of such education were as follows: threatened national identities (Germany) and biased perception of the Holocaust history (Poland). Neither of them could be considered a desired outcome of Holocaust education.

As an alternative to dominant forms of Holocaust education, we propose three approaches that are not based on national identities, national-level emotions (guilt, shame, pride) and national-level responsibilities. First of them, empathic education, leads to greater focus on victims experiences and generates feelings of regret instead of collective guilt. The second, moral-exemplars approach, stresses the diversity of behaviours in times of the Holocaust presenting individual heroism as a counterpoint to the passivity or cruelty of others. Such way of education about the Holocaust allows to overcome essentialist and entitative perceptions of groups. The third approach, based on local identities, aims to include the victims into the common local identity, and to acknowledge the losses in the local Jewish population.

Holocaust education is often considered not only a part of historical education, but also an important experience that could prevent future crimes, cruelty and conflicts. The success of such endeavour lies in the ability of educators to utilize the psychological knowledge in their teaching about the Holocaust, in order to better understand potential obstacles and being able to overcome them.

\section{Notes}

1. Although it is clear that these three positions are merely constructions of collective memory, as in every nation there were individuals in perpetrator, collaborator, passive bystander, and victim role, whereas the process of genocide was transforming people and groups from one role to another (Bilewicz and Vollhardt 2012).

2. More than a half of these visitors could be classified as having intrusionrelated symptoms, about a quarter developed avoidance symptoms and more than $10 \%$ showed hypervigilance symptoms.

3. This research was supported by the DFG-NCN Beethoven grant (2014/15/G/HS6/04589). 


\section{REFERENCES}

Abram, I., \& Heyl, M. (1996). Thema Holocaust. Ein Buch für die Schule. Reinbek: Rewohlt.

Ahlheim, K., \& Heger, B. (2002). Die unbequeme Vergangenheit. NS-Vergangenheit, Holocaust und die Schwierigkeiten des Erinnerns. Schwalbach: Wochenschau-Verlag.

Allwork, L. (2015). Holocaust remembrance between the national and the transnational: The Stockholm international formm and the first decade of the international task force. London: Bloomsbury Publishing.

Ambrosewicz-Jacobs, J., \& Szuchta, R. (2014). The intricacies of education about the Holocaust in Poland. Ten years after the Jedwabne debate, what can Polish school students learn about the Holocaust in history classes? Intercultural Education, 25, 283-299.

Anderson, J. R. (2007). Kognitive Psychologie. 6. Auflage. Berlin: Spektrum.

Assmann, A. (2010). The Holocaust-A global memory? Extensions and limits of a new memory community. In A. Assmann \& S. Conrad (Eds.), Memory in a global age. Discourses, practices and trajectories (pp. 97-117). London: Palgrave Macmillan UK.

Bar-On, D., Hare, A. P., Brusten, M., \& Beiner, F. (1997). Den Holocaust 'durcharbeiten'? Ergebnisse einer vergleichenden Untersuchung an deutschen und israelischen Studierenden. In D. Bar-On, K. Brendler, \& A. P. Hare (Eds.), "Da ist etwas kaputtgegangen an den Wurzeln...": Identitätsformation deutscher und israelischer Jugendlicher im Schatten des Holocaust (pp. 21-53). Frankfurt am Main: Campus.

Baumeister, R. F., Stillwell, A. M., \& Heatherton, T. F. (1995). Personal narratives about guilt: Role in action control and interpersonal relationships. Basic and Applied Social Psychology, 17, 173-198.

Bilewicz, M. (2007). History as an obstacle: Impact of temporal-based social categorizations on Polish-Jewish intergroup contact. Group Processes \& Intergroup Relations, 10, 551-563.

Bilewicz, M. (2016). The dark side of emotion regulation: Historical defensiveness as an obstacle in reconciliation. Psychological Inquiry, 2, 89-95.

Bilewicz, M., \& Jaworska, M. (2013). Reconciliation through the righteous: The narratives of heroic helpers as a fulfillment of emotional needs in PolishJewish intergroup contact. Journal of Social Issues, 69, 162-179.

Bilewicz, M., \& Vollhardt, J. R. (2012). Evil transformations: Psychological processes underlying genocide and mass killing. In A. Golec De Zavala \& A. Cichocka (Eds.), Social psychology of social problems. The intergroup context (pp. 280-307). New York: Palgrave Macmillan.

Bilewicz, M., Witkowska, M., Stefaniak, A., \& Imhoff, R. (2016). The lay historian explains intergroup behavior: Identification and epistemic abilities as 
correlates of ethnocentric historical attributions. Manuscript submitted for publication.

Bilewicz, M., \& Wójcik, A. (2009). Antysemityzm na gruzach sztetl: stosunek polskiej młodzieży do Żydów w miastach i miasteczkach południowej i wschodniej Polski. W: LM Nijakowski (red.), Etniczność, pamięć, asymilacja: wokół problemów zachowania tożsamości mniejszości narodowych i etnicznych, 153-167.

Bilewicz, M., \& Wójcik, A. (2016). Visiting Auschwitz. Evidence of secondary traumatization of high-school students. Manuscript submitted for publication.

Brandt, S. (2003). Wenig Anschauung? Die Ausstrahlung des Films Holocaust im westdeutschen Fernsehen. In C. Cornelißen, L. Klinkhammer, \& W. Schwentker (Eds.), Erinnerungskulturen. Deutschland, Italien und Japan seit 1945 (pp. 257-268). Frankfurt am Main: Fischer.

Branscombe, N. R., Doosje, B., \& McGarty, C. (2002). Antecedents and consequences of collective guilt. In D. M. Mackie \& E. R. Smith (Eds.), From prejudice to intergroup emotions: Differentiated reactions to social groups (pp. 49-66). New York: Psychology Press.

Branscombe, N. R., Schmitt, M. T., \& Schiffhauer, K. (2007). Racial attitudes in response to thoughts of White privilege. European Journal of Social Psychology, $37,203-215$.

Brendler, K. (1994). Die Holocaustrezeption der Enkelgeneration im Spannungsfeld von Abwehr und Traumatisierung. Jabrbuch für Antisemitismusforschung, 3, 303-340.

Brendler, K. (1997a). Vorwort. In D. Bar-On, K. Brendler, \& A. P. Hare (Eds.), "Da ist etwas kaputtgegangen an den Wurzeln...": Identitätsformation deutscher und israelischer Jugendlicher im Schatten des Holocaust (pp. 7-9). Frankfurt am Main: Campus.

Brendler, K. (1997b). Die NS-Geschichte als Sozialisationsfaktor und Identitätsballast der Enkelgeneration. In D. Bar-On, K. Brendler, \& A. P. Hare (Eds.), "Da ist etwas kaputtgegangen an den Wurzeln...": Identitätsformation deutscher und israelischer Jugendlicher im Schatten des Holocaust (pp. 53-105). Frankfurt am Main: Campus.

Brockhaus G. (2008). "Bloß nicht moralisieren!” - Emotionale Prozesse in der pädagogischen Auseinandersetzung mit dem Nationalsozialismus. Einsichten und Perspektiven, 1, 28-33.

Broder, H. M. (1986). Der Ewige Antisemit. Über Sinn und Funktion eines beständigen Gefübls. Frankfurt am Main: Fischer.

Brown, R., González, R., Zagefka, H., Manzi, J., \& Čehajić, S. (2008). Nuestra culpa: Collective guilt and shame as predictors of reparation for historical wrongdoing. Journal of Personality and Social Psychology, 94, 75-90.

Brown, R., Vivian, J., \& Hewstone, M. (1999). Changing attitudes through intergroup contact: The effects of group membership salience. European Journal of Social Psychology, 29, 741-764. 
Brusten, M., \& Winkelmann, B. (1992). The understanding of the Holocaust and its influence on current perspectives of German youth. Soziale Probleme, $3,1-27$.

Brusten, M., \& Winkelmann, B. (1994). Wie denken deutsche Studenten in "West" und "Ost" nach der Wiedervereinigung über den Holocaust. In D. Diner \& F. Stern (Eds.), Tel Aviver Jahrbuch für deutsche Geschichte. Nationalismus aus heutiger Perspektive (pp. 461-486). Gerlingen: Bleicher Verlag.

Carrier, P., Fuchs, E., \& Messinger, T. (2015). The International status of education about the Holocaust: A global mapping of textbooks and curricula. Paris: UNESCO Publishing and Georg Eckert Institute.

Čehajić-Clancy, S., \& Bilewicz, M. (2016). Fostering reconciliation through historical moral exemplars in a post-conflict society. Manuscript submitted for publication.

Cisneros, D. (2008). Unterricht aus Lehrerperspektive. Einsichten und Perspektiven, 1, 44-51.

Easterbrook, J. A. (1959). The effect of emotion on cue utilization and the organization of behaviour. Psychological Review, 66(3), 183-201.

Fend, H. (1991). Identitätsentwicklung in der Adoleszenz. Lebensentwürfe, Selbstfindung und Weltaneignung in beruflichen, familiären und politischweltanschaulischen Bereichen. Entwicklungspsychologie der Adoleszenz in der Moderne (Bd. 2). Bern: Huber.

Ferguson, M. A., \& Branscombe, N. R. (2014). The social psychology of collective guilt. In C. von Scheve \& M. Salmela (Eds.), Collective emotions (pp. 251-265). New York: Oxford University Press.

Gaertner, S. L., Dovidio, J. F., Anastasio, P. A., Bachman, B. A., \& Rust, M. C. (1993). The common ingroup identity model: Recategorization and the reduction of intergroup bias. European Review of Social Psychology, 4, 1-26.

Glück, E. M., \& Wagensommer, G. (2004). Erinnern ist mehr als Informiertsein. In W. Schwendemann \& G. Wagensommer (Eds.), Erinnern ist mehr als Informiertsein. Aus der Geschichte Lernen (2) (pp. 97-109). Münster: LITVerlag.

Golec de Zavala, A., Cichocka, A., \& Bilewicz, M. (2013). The paradox of ingroup love: Differentiating collective narcissism advances understanding of the relationship between in-group and out-group attitudes. Journal of Personality, 81, 16-28.

Gross, J. T. (2001). Neighbors: The destruction of the Jewish community in Jedwabne, Poland. Princeton: Princeton University Press.

Gross, M. H. (2010). Rewriting the nation: World War II narratives in Polish history textbooks. In I. Silova (Ed.), Post-socialism is not dead: (Re)reading the global in comparative education (pp. 213-246). Bingley: Emerald Group Publishing Limited. 
Gross, M. H. (2014). Struggling to deal with the difficult past: Polish students confront the Holocaust. Journal of Curriculum Studies, 46, 441-463.

Henke-Bockschatz, G. (2004). Der "Holocaust" als Thema im Geschichtsunterricht. Kritische Anmerkungen. In W. Meseth, M. Proske, \& F. O. Radke (Hrsg.), Schule und Nationalsozialismus. Anspruch und Grenzen des Geschichtsunterrichts (S. 9-32). Frankfurt a. M.: Campus.

Hewstone, M., Cairns, E., Voci, A., McLernon, F., Niens, U., \& Noor, M. (2004). Intergroup forgiveness and guilt in Northern Ireland: Social psychological dimensions of 'The Troubles'. In N. R. Branscombe \& B. Doosje (Eds.), Collective guilt: International perspectives (pp. 193-215). Cambridge: University Press.

Heyl, M. (1996). "Erziehung nach Auschwitz" und "Holocaust Education" Überlegungen, Konzepte und Vorschläge. In I. Abram \& M. Heyl (Eds.), Thema Holocaust. Ein Buch für die Schule (pp. 61-164). Reinbek: Rewohlt.

Imhoff, R., \& Banse, R. (2009). Ongoing victim suffering increases prejudice: The case of secondary anti-Semitism. Psychological Science, 20, 1443-1447.

Imhoff, R., Bilewicz, M., \& Erb, H. (2012). Collective regret versus collective guilt: Different emotional reactions to historical atrocities. European Journal of Social Psychology, 42, 729-742.

Imhoff, R., Bilewicz, M., Hanke, K., Kahn, D. T., Henkel-Guembel, N., Halabi, S., et al. (in press). Explaining the inexplicable: Differences in attributions for the Holocaust in Germany, Israel and Poland. Political Psychology.

Imhoff, R., Wohl, M. J. A., \& Erb, H. (2013). When the past is far from dead: How ongoing consequences of genocides committed by the ingroup impact collective guilt. Journal of Social Issues, 69, 74-91.

Keupp, H. (2008). Editorial. Einsichten und Perspektiven, 1, 4-5.

Kofta, M., \& Slawuta, P. (2013). Thou shall not kill... your brother: Victim-perpetrator cultural closeness and moral disapproval of Polish atrocities against Jews after the Holocaust. Journal of Social Issues, 69, 54-73.

Krejci, J. (1995). Die Suche nach einer neuen nationalen und europäischen Identität bei Deutschen, Tschechen und Polen. Frankfurt a. M.: Peter Lang.

Kühner, A., \& Langer, P. (2008). Wie Geschichte zum Thema wird. "Holocaust Education" aus sozialpsychologischer Perspektive. Psychosozial, 114, 131-141.

Lange, A. (2008). A survey of teachers' experiences and perceptions in relation to teaching about the Holocaust. Stockholm: Living History Forum.

Leach, C. W., Bou Zeineddine, F., \& Čehajić-Clancy, S. (2013). Moral immemorial: The rarity of self-criticism for previous generations' genocide or mass violence. Journal of Social Issues, 69, 34-53.

Lewicka, M. (2008). Place attachment, place identity, and place memory: Restoring the forgotten city past. Journal of Environmental Psychology, 28, 209-231.

Lewicka, M. (2012). Psychologia miejsca. Warsaw: Wydawnictwo Naukowe Scholar. 
Maitner, A. T., Mackie, D. M., \& Smith, E. R. (2007). Antecedents and consequences of satisfaction and guilt following ingroup aggression. Group Processes \& Intergroup Relations, 10, 223-237.

Mayer, U., Pandel, H. J., Schneider, G., \& Schönemann, B. (Hrsg.). (2006). Wörterbuch Geschichtsdidaktik (S. 90-91). Schwalbach: Wochenschau Verlag.

Mazur, L. B., \& Vollhardt, J. R. (2015). The prototypicality of genocide: Implications for international intervention. Analyses of Social Issues and Public Policy (Advanced online publication).

Meier, C. (1997). Debatte: Goldhagen und die Deutschen. Internationale Zeitschrift für Philosophie, 1, 119-123.

Miller, N. (2002). Personalization and the promise of contact theory. Journal of Social Issues, 58, 387-410.

Ministerium für Schule und Weiterbildung des Landes Nordrhein-Westfalen. (2007). Kernlehrplan für das Gymnasium-Sekundarstufe I (G8) in Nordrhein-Westfalen. Geschichte. Frechen: Ritterbach.

Mummendey, A., Klink, A., \& Brown, R. (2001). Nationalism and patriotism: National identification and out-group rejection. British Journal of Social Psychology, 40, 159-172.

Peetz, J., Gunn, G. R., \& Wilson, A. E. (2010). Crimes of the past: Defensive temporal distancing in the face of past in-group wrongdoing. Personality and Social Psychology Bulletin, 36, 598-611.

Reichel, P. (2004). Erfundene Erinnerung: Weltkrieg und Judenmord in Film und Theater. Munich/Vienna: Carl Hanser Verlag.

Riley, K. L. (1998). Historical empathy and the Holocaust: Theory into practice. International Journal of Social Education, 13, 32-42.

Rommelspacher, B. (1995). Schuldlos - Schuldig? Wie sich junge Frauen mit Antisemitismus auseinandersetzen. Hamburg: Konkret-Literatur-Verlag.

Schmidt-Denter, U. (2011). Die Deutschen und ibre Migranten. Ergebnisse der europäischen Identitätsstudie. Weinheim: Juventa.

Schmidt-Denter, U., \& Stubig, S. (2011). Holocaust Education: Lehrplanrecherche, TV-Recherche und Untersuchungen. (Forschungsbericht Nr. 35 zum Projekt "Personale und soziale Identität im Kontext von Globalisierung und nationaler Abgrenzung”). Cologne: Universität.

Schneider, W. L. (2004). Die Unwahrscheinlichkeit der Moral. Strukturen moralischer Kommunikation im Schulunterricht über Nationalsozialismus und Holocaust. In W. Meseth, M. Proske, \& F. O. Radke (Eds.), Schule und Nationalsozialismus. Anspruch und Grenzen des Geschichtsunterrichts (pp. 205-234). Frankfurt am Main: Campus.

Schultz, L. H., Barr, D. J., \& Selman, R. L. (2001). The value of a developmental approach to evaluating character development programmes: An outcome study of facing history and ourselves. Journal of Moral Education, 30, 3-27. 
Schwendemann, W. (2004). Didaktisches Chaos oder alles im Griff? Aspekte einer Erziehung nach und über Auschwitz. In W. Schwendemann \& G. Wagensommer (Eds.), Erinnern ist mehr als Informiertsein. Aus der Geschichte lernen (2) (pp. 33-47). Münster: LIT-Verlag.

Schwendemann, W. \& Marks, S. (2002). Unterrichtsthema "Nationalsozialismus" in einer Hauptschule - Ergebnisse einer Pilotstudie (Schülerbefragungen). Im Gespräch: Hefte der Martin Buber-Gesellschaft, 3, 62-77.

Smith, T. W., \& Jarkko, L. (1998). National pride: A cross-national analysis (GSS Cross-national Report No. 19). Chicago: National Opinion Research Centre/ University of Chicago.

Smith, T. W., \& Seokho, K. (2006). National pride in comparative perspective: 1995/96 and 2003/04. International Journal of Public Opinion Research, 18, 127-136.

Stefaniak, A., \& Bilewicz, M. (2016). Contact with a multicultural past: A prejudice-reducing intervention. International Journal of Intercultural Relations, $50,60-65$.

Stubig, S. S. (2015). Die Wirkung des Geschichtsunterrichts zu Nationalsozialismus und Holocaust auf die Identitüt von Jugendlichen. Aachen: Shaker.

Szuchta, R. (2006). Nauczanie o Holokauście - zalecenia programowe a praktyka szkolna. In A. Żbikowski (Ed.), Nauczanie o Holokauście (pp. 75-83). Pułtusk: ASPRA-JR.

Szuchta, R. (2013). Czego uczeń polskiej szkoty może się dowiedzieć o Holokauście na lekcji historii dziesięć lat po "dyskusji jedwabienskiej”? Unpublished manuscript.

Szuchta, R., \& Trojański, P. (2012). Jak uczyć o Holokanście: Poradnik metodyczny do nauczania o Holokauście w ramach przedmiotów humanistycznych w zreformowanej szkole. Warsaw: Ośrodek Rozwoju Edukacji.

Tajfel, H., \& Turner, J. C. (1979). An integrative theory of intergroup conflict. The Social Psychology of Intergroup Relations, 33(47), 74.

Tangney, J. P. (1995). Shame and guilt in interpersonal relationships. In J. P. Tangney \& K. W. Fischer (Eds.), Self-conscious emotions: The psychology of shame, guilt, embarrassment, and pride (pp. 114-139). New York: Guilford Press.

Welzer, H. (2004). “Ach Opa!” Einige Bemerkungen zum Verhältnis von Tradierung und Aufklärung. In W. Meseth, M. Proske, \& F. O. Radke (Eds.), Schule und Nationalsozialismus. Anspruch und Grenzen des Geschichtsunterrichts (pp. 49-64). Frankfurt am Main: Campus.

Westle, B. (1999). Kollektive Identität im vereinten Deutschland. Nation und Demokratie in der Wahrnehmung der Deutschen. Opladen: Leske + Budrich. 
Węgrzynek, H. (2006). Prezentacja Holokaustu i dziejów Żydów w aktualnych podręcznikach historii. In A. Żbikowski (Ed.), Nauczanie o Holokauście (pp. 13-74). Pułtusk: ASPRA-JR.

Witkowska, M., \& Bilewicz, M. (2014). Czy prawda nas wyzwoli? Przełamywanie oporu psychologicznego w przyjmowaniu wiedzy o Holocauście. Zagtada Żydów. Studia i materiaty, 10, 805-822.

Witkowska, M., Bilewicz, M., \& Čehajić-Clancy, S. (2016). Fostering intergroup contact after historical atrocities. An approach based on moral exemplars. Unpublished manuscript.

Witkowska, M., Stefaniak, A., \& Bilewicz, M. (2015). Stracone szanse? Wpływ polskiej edukacji o Zagładzie na postawy wobec Żydów. Psychologia Wychowawcza, 5, 147-159.

Wohl, M. J., \& Branscombe, N. R. (2005). Forgiveness and collective guilt assignment to historical perpetrator groups depend on level of social category inclusiveness. Journal of Personality and Social Psychology, 88, 288-303.

Wójcik, A., \& Bilewicz, M. (2012). Oświęcim inaczej. Raport z badań. [Auschwitz in a different way. Research report]. Warsaw: Center for Research on Prejudice.

Wójcik, A., Bilewicz, M., \& Lewicka, M. (2010). Living on the ashes: Collective representations of Polish-Jewish history among people living in the former Warsaw Ghetto area. Cities, 27, 195-203.

Zülsdorf-Kersting, M. (2007). Sechzig Jahre danach: Jugendliche und der Holocaust. Eine Studie zur geschichtskulturellen Sozialisation. Münster: LITVerlag.

\section{Authors' Biography}

Michał Bilewicz is an Associate Professor of Psychology at the University of Warsaw, where he chairs the Center for Research on Prejudice. His research concerns social psychology of intergroup relations, particularly the problems of post-conflict reconciliation, the aftermath of mass violence and hate speech. As vice-president of the Forum for Dialogue, he was involved in creating teaching materials about multi-ethnic history and novel educational methods. $\mathrm{He}$ was co-chairing the Working Group on collective emotions and reconciliation within the COST IS1205 research network, and he currently serves as Governing Council member of the International Society of Political Psychology. He published numerous articles, e.g., in Psychological Inquiry, International Journal of Conflict and Violence, Group Processes and Intergroup Relations and European Journal of Social Psychology. He is a member of Editorial Boards of European 
Journal of Social Psychology, International Journal of Intercultural Relations and Journal of Community and Applied Social Psychology.

Marta Witkowska is a doctoral candidate at the Department of Psychology at the University of Warsaw. She works within NCN-DFG research grant Beethoven on the role of psychological motivations in historical representations. Her current research concerns the role of moral exemplars in reconciliation (portrayals of heroic helpers in times of genocide). Apart from psychological research, she is also active in antidiscriminatory education (e.g. Human Library project in Radom). She published several chapters and articles about the holocaust education in Poland and potentials for alternative education.

Silviana Stubig is a Senior Lecturer at the Department of Psychology at the University of Cologne. Her research concerns issues of Pedagogical Psychology and Developmental Psychology. Her doctoral dissertation dealt with the topic of Holocaust Education in German classes and was published in 2015. Actual research projects concentrate on smartphone usage in learning contexts.

Marta Beneda completed an MA in Psychology at the University of Warsaw in 2016 and is currently pursuing an MA in Social and Developmental Psychology at the University of Cambridge. Since 2013, she has been a part of the Centre for Research on Prejudice at the University of Warsaw where she has been engaged in several projects focused on the social psychology of intergroup relations. Her main research interests include the role of historical narratives in intergroup reconciliation and forgiveness, prejudice reduction and the role of social and cognitive processes in gender development.

Roland Imhoff is Chair for Social and Legal Psychology at the Johannes Gutenberg University (JGU) Mainz, Germany, and a board member of the Center for Interdisciplinary Forensics at the JGU Mainz. His research interests lie in the areas of social psychological approaches to intergroup conflict and history, stereotypes and prejudice, ideology and conspiracy thinking as well as sexual orientation and methodological and measurement issues. Exploring and pushing the boundaries of his field, he has been part of interand transdisciplinary research centres with economists, legal scholars, medical scholars, sociologists, historians and other disciplines. He has published papers in Journal of Personality and Social Psychology, Psychological Science, 
Perspectives on Psychological Science, Psychological Assessment, Emotion and European Journal of Social Psychology, among others. Since 2011, he is a member of the Editorial Board of the Archives of Sexual Behavior.

Open Access This chapter is licensed under the terms of the Creative Commons Attribution 4.0 International License (http://creativecommons.org/licenses/ by $/ 4.0 /$ ), which permits use, sharing, adaptation, distribution and reproduction in any medium or format, as long as you give appropriate credit to the original author(s) and the source, provide a link to the Creative Commons license and indicate if changes were made.

The images or other third party material in this chapter are included in the chapter's Creative Commons license, unless indicated otherwise in a credit line to the material. If material is not included in the chapter's Creative Commons license and your intended use is not permitted by statutory regulation or exceeds the permitted use, you will need to obtain permission directly from the copyright holder.

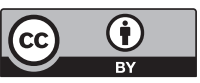

